\title{
Validity of the social support assessment scale in mothers of hospitalized premature neonates
}

\author{
Validade da escala para avaliação do apoio social em \\ mães de neonatos prematuros hospitalizados
}

\author{
Maihana Maira Cruz Dantas FONSECA ${ }^{1}$ [D) 0000-0002-6190-8050 \\ Heloísa Karmelina Carvalho de SouSA ${ }^{2}$ iD) 0000-0001-7722-6874 \\ Brenda Albuquerque Adriano da SILVA ${ }^{3}$ (iD) 0000-0002-5384-0084 \\ João Carlos ALCHIERI ${ }^{4}$ iD) 0000-0002-4150-8519 \\ Eulália Maria Chaves MAIA ${ }^{3}$ iD 0000-0002-0354-7074
}

\begin{abstract}
Mothers staying with their premature babies, hospitalized in the Neonatal Intensive Care Unit tend to have reduced contact with friends and family, so it is pertinent that the perceived social support be evaluated during this period. This study aims to verify the validity of the Scale to evaluate the perceived social support by mothers of hospitalized premature babies. It is composed by the following dimensions: affective support; material support; informational support; emotional support; embracing support; and attentional support. It is a sectional analytical study. The participants were 218 mothers of premature babies hospitalized in the Neonatal Intensive Care Unit. The social support Scale for mothers of hospitalized premature neonates demonstrates satisfactory psychometric quality, presenting evidence of criterion validity, internal consistency and internal structure.
\end{abstract}

Keywords: Infant, premature; Intensive care units, neonatal; Mother-child relationships.

$\operatorname{rrv}$

1 Psicóloga. Natal, RN, Brasil.

2 Universidade de Pernambuco, Departamento de Psicologia. Garanhuns, PE, Brasil.

3 Universidade Federal do Rio Grande do Norte, Departamento de Psicologia, Programa de Pós-Graduação em Psicologia. Av. Senador Salgado Filho, 3000, Lagoa Nova, 59078 970, Natal, RN, Brasil. Correspondence to: E.M.C. MAIA. E-mails: <eulalia.maia@yahoo.com.br>; $<$ maihanacruz@gmail.com>.

${ }^{4}$ Universidade Federal do Rio Grande do Norte, Departamento de Psicologia, Programa de Pós-Graduação em Ciência, Tecnologia e Inovação. Natal, RN, Brasil.

Support: Coordenação de Aperfeiçoamento de Pessoal de Nivel Superior.

Article elaborated from the thesis of M.M.C.D. FONSECA, entitled "Apoio social em mães de bebês prematuros hospitalizados: elaboração e evidência de validade de um instrumento". Universidade Federal do Rio Grande do Norte, 2016.

$\because \cos$

How to cite this article

Fonseca, M. M. C. D., Sousa, H. K. C., Silva, B. A. A., Alchieri, J. C., \& Maia, E. M. C. (2021). Validity of the social support assessment scale in mothers of hospitalized premature neonates. Estudos de Psicologia (Campinas), 38, e190112. https://doi.org/10.1590/1982-0 $275202138 \mathrm{e} 190112$ 


\section{Resumo}

As mães acompanhantes de bebês prematuros que estão hospitalizados em Unidades de Terapia Intensiva Neonatal tendem a ter reduzido o seu contato com amigos e familiares, por isso é pertinente que o apoio social percebido seja avaliado durante esse período. Este estudo tem como objetivo verificar evidências de validade da Escala para avaliação do apoio social percebido por mães de bebês prematuros hospitalizados, que é composta pelas dimensões: apoio afetivo; apoio material; apoio de informação; apoio emocional; apoio de acolhimento e apoio de atenção. Trata-se de um estudo seccional analítico do qual participaram 218 mães de bebês prematuros hospitalizados na Unidade de Terapia Intensiva Neonatal. A Escala para avaliação do apoio social em mães de neonatos prematuros hospitalizados demonstra qualidade psicométrica satisfatória, apresentando evidências de validade de critério, de consistência interna e de estrutura interna.

Palavras-chave: Recém-nascido prematuro; Unidades de terapia intensiva neonatal; Relações mãe-filho.

Social support is related to the resources made available, thus demonstrating how much the individual is socially integrated, the degree to which interpersonal relationships satisfy certain functions and the necessary support in times of crisis or readaptation (Zanini, Peixoto, \& Makato, 2018). It is characterized as a multidimensional construct that encompasses the comfort, assistance and/or information that a person receives from their formal or informal network, being associated with the perception by individuals of their social world (Cardoso \& Vivian, 2017). There is no unanimous definition in the literature in relation to the dimensions presented, however, five are frequently mentioned: material, emotional, positive social interaction, affective and informational support (Griep, Chor, Faerstein, Werneck, \& Lopes 2005; Sherbourne \& Stewart, 1991).

Evidence indicates that, in certain situations or contexts, the family and social support received by the individual positively influences mental health in women during the pregnancy-puerperium cycle (Monteiro et al., 2018). The puerperium is the period characterized as an intense moment of emotional experiences for the mother, causing a high psychological risk. In addition to undergoing biological transformations, the puerperal woman still has to deal with the varied demands of the postpartum period, such aspects make women more vulnerable to presenting some type of mental disorder (Almeida \& Arrais, 2016; Higuti \& Capocci, 2003).

Regarding the prevalence of premature births, there are approximately fifteen million premature babies in the world, that is, a baby born before completion of the $37^{\text {th }}$ gestational week (Word Health Organization, 2018). In this context, the occurrence of a premature birth and the hospitalization of the newborn in the Neonatal Intensive Care Unit (NICU) can be a traumatic and distressing event for the parents (Russel et al., 2014). Despite the importance of hospitalization, it causes the separation of the mother-baby dyad, causing ambivalent and intense feelings in the puerperium, such as guilt, inferiority, distress, anguish, despair, estrangement, fear, emptiness and impotence, consequently influencing the relationship with the baby (Baseggio, Dias, Brusque, Donelli, \& Mendes, 2017).

The NICU environment, due to its distinct characteristics from the previous intrauterine environment, is uncomfortable and cold and can intervene in the mother-baby bond, due to the complexity of procedures, in addition to the variety of professionals who work and perform interventions in neonates, resulting in an increase in the levels of anxiety, melancholy and sadness of the mothers (Schaefer \& Donelli, 2017). Due to hospitalization, mothers often need to stay in the hospital, staying with their babies. This is due to the rules of many institutions, cultural aspects, as well as breastfeeding (Zanfolim, Cerchiari, \& Ganassin, 2018).

When in the hospital environment, the puerperal woman leaves her social and family life aside for

2 the care of the newborn (Zanfolim et al., 2018), experiencing different difficulties related to long hospital 
periods: lack of experience, insecurity, fatigue, stress, feelings of sadness and anxiety, homesickness, feeling concerned, and the need to adapt to the hospital routine and transferring the care of the family to another family member (Contim et al., 2017). The mother becomes more fragile and in greater need of family support, which makes her feel protected. When she receives adequate support, the puerperal woman gradually adapts to the hospital routine, managing to take care of the newborn and demystifying the perception that her child is very fragile (Ministério da Saúde, 2017).

In the international scenario, some studies were carried out with the objective of elaborating and validating instruments that evaluate social support in the postpartum period, as well as in the puerperal period of mothers of neonates admitted to the NICU. Such studies emphasize the importance of creating and validating instruments for this period (Hopkins \& Campbell, 2008; Montirosso, Provenzi, Calciolari, \& Borgatti, 2011). Therefore, it is important to develop a scale that assesses social support for mothers of premature newborns hospitalized in the NICU who reside in Brazil.

The use of an instrument with satisfactory validity indexes can help health professionals to assess the perceived social support by mothers of premature babies who are in the NICU, enabling the healthcare team to identify mothers who are perceiving themselves as being with reduced social support, which may leave professionals more aware of the need for possible interventions. This article seeks to verify evidence of validity of the Scale instrument to assess the perceived social support by mothers of hospitalized premature babies.

\section{Method}

This is an analytical sectional study, whose data collection was carried out from April 2015 to May 2016, after the approval by the Research Ethics Committee of the Universidade Federal do Rio Grande do Norte (UFRN, Federal University of Rio Grande do Norte), protocol number 488.249 and the Certificado de Apresentação para Apreciação Ética (CAAE, Presentation Certificate for Ethical Appreciation) protocol number 22735313.5.0000.5537.

\section{Participants}

The participants were 218 mothers of premature babies hospitalized in the NICU. The following inclusion criteria were adopted: mothers with preterm newborn babies who were born more than 24 hours ago and admitted to the NICU; being 18 years of age or older; accepting to participate in the research, by signing the informed consent term. Exclusion criteria were defined as: parents of neonates who died and parents who were in the Maternal Intensive Care Unit.

Regarding age, $46.79 \%$ of participants were between 18 and 25 years old, $40.37 \%$ were between 26 and 35 years old and $12.84 \%$ were over 35 years old. Most puerperal women $(66.51 \%)$ lived in the countryside and $33.49 \%$ in the state capital. A total of $55.05 \%$ reported that they were in a stable relationship, $23.85 \%$ were married and $21.10 \%$ were single. Of these women, $83.49 \%$ said that they had some kind of religious practice and $16.51 \%$ reported not having any frequent religious practices. As for the mothers' biodemographic information, $60.65 \%$ had a cesarean delivery and $39.35 \%$ had a normal delivery. Moreover, 58.80\% experienced complications during pregnancy, $26.85 \%$ experienced complications during delivery and $25.12 \%$ experienced complications after delivery. The mean number of pregnancies was 2.22 and Standard Deviation (SD) was 2.02. In addition, 96.74\% reported having performed prenatal care, with an average number of prenatal medical appointments of 6.30 and SD 
of 3.52. According to the baby data collected, $50.23 \%$ were girls and $49.77 \%$ were boys with an average gestational age of 30.95 weeks with a $S D$ of 3.66, and an average weight of 1,523.12 grams with a SD of 687.01 .

\section{Instruments}

As a tool, the Social Support - as perceived by mothers of hospitalized premature babies Assessment Scale was used, composed of the following dimensions: affective support; material support; informational support; emotional support; embracing support; attentional support. The referred Scale contains 36 items, of the Likert type, with three possibilities of answer, being these: less than you would like $=1$; almost as much as you would like $=2$; as much as you would like $=3$. Thus, the minimum score that can be obtained on the instrument is 36 and the maximum is 108 . To reach the total score for each dimension, the results should be calculated according to the number of items included in each dimension.

To investigate the criterion validity, it was decided to use two questions present in the sociobiodemographic questionnaire: Do you feel supported in your baby's hospitalization situation? In a dichotomized alternative, yes or no; give a rating from 0 to 10 to the perceived support during the neonate's current hospitalization situation. The choice to use these questions was due to the difficulty of accessing a standard instrument to obtain self-reported data from the mother.

Considering the construct "Social Support" as multidimensional, Cronbach's Alpha was used to assess the internal consistency of each of the dimensions, being respectively: affective support $(\alpha=0.904)$, material $(\alpha=0.905)$, informational $(\alpha=0.901)$, emotional $(\alpha=0.899)$, embracing $(\alpha=0.899)$ and attentional $(\alpha=0.901)$. An overall alpha value of 0.92 was found.

\section{Procedures}

The instrument was administered in the format of individual interviews, during the period the mother was with her baby, with an approximate duration of 10 minutes. The conduction of an interview was justified as a way to administer the instrument due to the inherent needs of a hospital environment, the vicissitudes of being the mother of a premature baby and the small duration of the interview in order to not interfere with the maternal care time.

\section{Data analysis}

The database was initially organized using Microsoft Windows Excel (version 2010), and the tables with the results of the descriptive statistics were generated. In order to carry out inferential analyzes, the Statistics IBM ${ }^{\circledR}$ SPSS ${ }^{\circledR}$ Software (version 20.0), was used, with the following procedures: Cronbach's alpha, ANOVA, Tukey's test, Pearson's correlation test, and exploratory factor analysis looking for indications of differences (or not) between the variables.

The principal component analysis is related to the explanation of the covariance structure through linear combinations of the original variables, aiming at reducing the original dimension of the variables and facilitating the interpretation of the analyzes performed. The decision criterion for the number of used factors to be selected to represent the latent structure of the data was the latent root criteria, which selects only the factors that the eigenvalues are greater than 1. Also, to support the decision of the retention criteria and criteria of extraction adopted, a Varimax rotation (6 interactions) was used, considering factorial loads 4 above "0.50" as significant (Mingoti, 2005). 


\section{Results}

The mean of the total score of the instrument was $90.85(S D=12.73)$, with a minimum value of 36 points and a maximum of 108.00. The mean of the affective support dimension was 24.69 (SD =4.00); material support, 22.56 ( $S D=4.36)$; informational, 14.77 ( $S D=2.89)$; emotional, 16.99 ( $S D=3.30$ ); embracing, 7.12 $(S D=1.70)$; and attentional, $4.73(S D=1.39)$.

The evidence of criterion validity verification of the constructed instrument was carried out based on the elaboration of two questions presented to the individuals who answered the sociodemographic questionnaire and further explained in the Method section. Mothers who reported feeling supported during their children's hospitalization at the NICU had higher values in the total score of the scale, with a strong statistical significance $(p=0.001)$ and in the following dimensions: affective support $(p=0.001)$; material support $(p=0.002)$, informational support $(p=0.001)$ and emotional support $(p=0.005)$.

Considering the association between the score attributed by the mothers to the social support received during the time of their babies' stay in the NICU, a moderate positive relationship was found between the total score $(r=0.42)$, affective support $(r=0.31)$, material support $(r=0.32)$, and informational support $(r=0.37)$, which can show satisfactory criterion validity. The emotional support $(r=0.29)$, embracing support $(r=0.21)$ and attentional support $(r=0.20)$ dimensions, in turn, showed statistically insignificant results with regard to the relationship with the scores given by the mothers to their perceived support. The aforementioned data indicate that the instrument has a strong evidence of criterion validity.

Six factors were selected, corresponding to $56.77 \%$ of the total result variability, being satisfactory to the percentage of the variance criterion, with a minimum explanation of $50.00 \%$ of the variability (Table 1). Then, the latent structure of the data was identified, using the latent root. Only factors with eigenvalues greater than 1 were considered (Table 2).

The factorial loads were identified after the selection of the factors, being calculated from the eigenvalues, thus determining the eigenvectors. The Varimax rotation, with 6 factors, was selected to enable the identification of the factorial loads representing each factor presented.

Although some items had a factorial load $<50.00 \%$ of variability - items $10(0.43)$ and $16(0.39)$-, the researchers opted for their permanence because the theoretical basis justifies the factors presented (Table 2). Factor 1 explained $29.31 \%$ of the total variability of the data set, with Q28 to Q36 as significant variables. Factor 2, in turn, represented $10.25 \%$ of the total variability, with significant variables from items Q19 to Q27. Factor 3 had the items Q1, Q3, Q4, Q7, Q13 and Q15 as significant, with a total variability of 5.08\%. Factor 4 consisted of Q2, Q8, Q9, Q11, Q12, Q14 and Q16, explained 4.10\% of the total variability, Factor 5 addressed Q10, Q17 and Q18, contemplating 3.75\% of total variability. Finally, Factor 6 (3.56\%) was composed of Q5 and Q6.

Table 1

Eigenvalue and explained variance percentage, Natal (RN), Brazil, 2016

\begin{tabular}{ccccc}
\hline Factor & Eigenvalue & \% of explained variance & Accumulated eigenvalue & \% of accumulated explained variance \\
\hline 1 & 10.56 & 29.31 & 10.56 & 29.31 \\
2 & 3.69 & 10.25 & 14.25 & 39.56 \\
3 & 2.09 & 5.80 & 16.33 & 45.36 \\
4 & 1.48 & 4.10 & 17.81 & 49.46 \\
5 & 1.35 & 3.75 & 19.16 & 53.21 \\
6 & 1.28 & 3.56 & 20.44 & 60.09 \\
7 & 1.19 & 3.32 & 21.63 & 63.01 \\
8 & 1.05 & 2.92 & 22.68 & \\
\hline
\end{tabular}


Table 2

Factorial loads in the composition of factors, Natal (RN), Brazil, 2016

\begin{tabular}{|c|c|c|c|c|c|c|}
\hline Questions & Factor 1 & Factor 2 & Factor 3 & Factor 4 & Factor 5 & Factor 6 \\
\hline Q1 & 0.02 & 0.09 & 0.67 & 0.30 & 0.05 & -0.12 \\
\hline Q2 & 0.06 & 0.18 & 0.03 & 0.71 & -0.02 & 0.09 \\
\hline Q4 & 0.01 & 0.13 & 0.54 & 0.05 & 0.20 & 0.17 \\
\hline Q5 & 0.08 & 0.12 & 0.12 & 0.15 & 0.03 & 0.80 \\
\hline Q6 & 0.06 & 0.08 & 0.21 & 0.22 & 0.12 & 0.76 \\
\hline Q7 & -0.01 & -0.01 & 0.83 & 0.13 & 0.04 & 0.11 \\
\hline Q8 & 0.17 & 0.00 & 0.31 & 0.57 & 0.21 & 0.02 \\
\hline Q9 & 0.13 & 0.13 & 0.28 & 0.56 & -0.09 & -0.02 \\
\hline Q10 & 0.11 & 0.10 & 0.23 & 0.32 & 0.43 & 0.15 \\
\hline Q11 & 0.03 & 0.21 & 0.27 & 0.55 & 0.09 & 0.04 \\
\hline Q12 & 0.19 & 0.05 & 0.15 & 0.61 & 0.06 & 0.28 \\
\hline Q13 & 0.16 & 0.06 & 0.54 & 0.31 & -0.09 & 0.23 \\
\hline Q14 & 0.09 & 0.16 & 0.12 & 0.53 & 0.30 & 0.15 \\
\hline Q15 & 0.19 & 0.09 & 0.63 & 0.32 & -0.05 & 0.09 \\
\hline Q16 & 0.35 & -0.04 & 0.06 & 0.39 & 0.34 & 0.18 \\
\hline Q18 & 0.14 & 0.25 & -0.05 & 0.08 & 0.73 & 0.14 \\
\hline Q19 & 0.27 & 0.54 & 0.28 & -0.01 & 0.37 & -0.11 \\
\hline Q20 & 0.24 & 0.65 & 0.23 & 0.13 & 0.22 & 0.05 \\
\hline Q21 & 0.18 & 0.58 & 0.08 & 0.11 & 0.19 & 0.08 \\
\hline Q22 & 0.26 & 0.56 & -0.10 & 0.26 & 0.04 & 0.10 \\
\hline Q23 & 0.10 & 0.62 & -0.01 & 0.02 & 0.09 & 0.07 \\
\hline Q24 & 0.18 & 0.75 & 0.00 & 0.09 & 0.04 & 0.10 \\
\hline Q25 & 0.33 & 0.52 & -0.05 & 0.18 & 0.05 & 0.05 \\
\hline Q26 & 0.31 & 0.58 & 0.20 & 0.00 & -0.10 & 0.05 \\
\hline Q27 & 0.18 & 0.58 & 0.16 & 0.14 & 0.12 & -0.08 \\
\hline Q28 & 0.68 & 0.36 & -0.05 & 0.13 & 0.10 & -0.01 \\
\hline Q29 & 0.72 & 0.34 & 0.07 & 0.16 & 0.07 & 0.08 \\
\hline Q30 & 0.77 & 0.20 & 0.08 & 0.14 & 0.16 & 0.07 \\
\hline Q31 & 0.79 & 0.15 & -0.01 & 0.15 & 0.03 & 0.14 \\
\hline Q32 & 0.75 & 0.23 & 0.14 & 0.13 & -0.02 & 0.04 \\
\hline Q33 & 0.80 & 0.16 & 0.17 & 0.12 & 0.07 & 0.11 \\
\hline
\end{tabular}

Note: Values in bold highlight the factor for which the item was considered representative.

\section{Discussion}

It can be observed that the objective of the study has been reached. The developed instrument has satisfactory validity and internal consistency indexes. But in addition to the statistical results, it is also important to consider its theoretical aspects (Figueiredo \& Silva, 2010).

In view of the internal structure evidence of validity, a factorial analysis was used, which identifies the grouping of items that can form one or more of one of the factors, being carried out through a statistical procedure. For these factors to be considered dimensions, it is necessary to provide theoretical support, which allows them to have their meanings assigned.

Thus, the first factor is composed of items 28 to 36. In the literature regarding perceived social support, it is part of the affective support dimension, which is characterized as demonstrations of love, tenderness and affection, arising from the network of support (Griep et al., 2005; Sherbourne \& Stewart, 1991). The literature argues that due to the distance from family life, the puerperal woman is often deprived of the tender and affectionate relationships between her, her children and her partner, with the feeling of longing for her closest family members being a feeling that is constantly reported (Dittz, Mota, \& Sena, 2008). The absence of affective support by the family for the mothers of babies hospitalized in the NICU was pointed out in the study by Zanfolim et al. (2018), highlighting the importance of the presence of family members during this period. Family members can be present through visits, calls, offering comfort and prayers, thus 
strengthening puerperal women. Friends also present themselves as important players, providing distraction from their stressful routine. And interactions with other mothers staying with their babies, who create a network of solidarity and support through mutual help (Almeida, Morais, Lima, \& Silva 2018).

The second factor includes items 19 to 27 . According to the literature, it refers to the material support dimension, which is related to aid in terms of behavior or material (Griep et al., 2005; Sherbourne \& Stewart, 1991); with items 19 to 27. Oliveira, Veronez, Higarashi, and Corrêa (2013) point out that puerperal women have needs related to operational and material issues, which directly interfere in the coping and elaboration of the newborn's hospitalization process. In addition to the lack of financial resources, there are still difficulties in commuting between their homes and hospitals, these factors hinder their stay with the baby in the NICU. In their study, Carvalho and Pereira (2017) found that some mothers mention the financial aspect as a difficulty they face because, during these periods in the hospital, families need to move from their cities located in the countryside and remain distant from their hometowns and families.

The third factor consists of items $1,3,4,7,13,15$, and is theoretically related to the informational support dimension. It refers to the availability of the social network to provide advice and guidance for the individual (Griep et al., 2005; Sherbourne, \& Stewart, 1991). Item 13: "one who understands what it is like to care for a premature baby" initially, from the analysis of the judges, it was part of the emotional support dimension. However, according to the reality of the mothers during the newborn's hospitalization period, the people who understand what it is like to care for a premature baby are those who can provide information. Parents tend to seek information about the diagnosis, as well as complications and risks to their child's survival. It is understood that this search enables parents to recognize the new reality and adapt to the emerging situation (Carvalho \& Pereira, 2017). Thus, the healthcare team is identified as a source of support during the hospitalization process. The interaction and support offered by these professionals are essential to face and facilitate this moment. The guidelines and specialized monitoring, which meet the dyad's assistance demands, contribute to the reduction of anxiety, as well as to the mothers' feeling of support and comfort (Oliveira et al., 2013). Therefore, it is relevant that professionals understand that humanized assistance does not happen only with the newborn, their parents should also be the focus of this care, allowing them to actively participate in the process (Coelho et al., 2018).

The fourth factor contains items $2,8,9,11,12,14,16$, concerning emotional support, that is, the individuals' perception that this support network understands them, being composed of people to whom they can talk without the fear of being judged (Griep et al., 2005; Sherbourne \& Stewart, 1991). Item 16 of the scale: "people to give you good advice", evaluated by the judges as relevant to compose the informational support dimension, however, presents a greater load in this factor, as it indicates the presence of someone who empathetically advises and embraces mothers. This result has theoretical support, since the other items of the emotional support dimension are related to the availability of the social support network to talk to the puerperal woman, providing an environment of empathy and acceptance. The importance of family members is highlighted in the study by Santos et al. (2013), which reports that the family reorganizes itself to help the puerperal woman, mainly caring for their emotional and psychological needs. With this, the mother feels more secure and confident to dedicate herself exclusively to the child. In addition, during the long stay in the hospital, mothers use different strategies to elaborate the suffering caused by the newborn's hospitalization process. In this sense, it is noted that they begin to relate to other mothers, building bonds of friendship, exercising solidarity and consoling each other. Thus, creating a common support network, to get through this period (Molina, Higarashi, \& Marcon, 2014).

The fifth factor, consists of the items: 10 "a person who may guide you on how to solve a problem"; 17 "a person whom you can count on in any situation of your life"; and 18 "a person to share your most intimate fears". Considering only data on the functional aspects of social support, it would not represent a theoretical dimension. However, the literature related to prematurity and hospitalization in the NICU allows 
the definition of this dimension, called embracing support. This dimension refers to "the perception that the mothers have people from their social network available to embrace them not only regarding their baby's care, but in all situations of their life" (Fonseca, 2016). Since they are companions in the NICU, they consequently have reduced contact with their support network, in this sense, the embracing support dimension demonstrates the need for them to be embraced and supported throughout their lives. It is relevant that this functional aspect of support during hospitalization is made available to them. This embracing by the family is essential during the hospitalization period, due to the intense emotional experiences, promoting a context of acceptance and helps to minimize their present suffering. The presence of family members in the NICU, in a free and spontaneous way, is a relevant alternative to alleviate suffering. Thus, it is necessary for the family to be seen as a constant in the life of the newborn who is in the NICU, and not only as a visitor to the newborn. For this reason, the often-strict rules of hospitals need to be made more flexible, aiming at the active participation of the members that compose the family nucleus (Santos et al., 2013).

The sixth factor is made up of items 5 "people to guide you in relation to your own healthcare practices" and 6 "people to give you information about how you should take care of your baby after leaving hospital", which initially had been designed to compose the informational support dimension. However, it was noted that they have a theoretical framework to constitute the attentional support dimension. The literature supports that these items constitute such a dimension. Therefore, this factor represents "the availability of the social support network to be attentive to the needs of the puerperal woman in relation to her own healthcare practices, as well as her insecurities regarding the care provided to the newborn after leaving hospital" (Fonseca, 2016). According to Simioni and Geib (2008), it is common for mothers to, after leaving hospital, to show feelings of abandonment and maternal incompetence. There were times in their homes that they needed support; however, this support did not materialize, resulting in feelings of disappointment, loneliness and incapacity. The mothers emphasize the absence of guidance from health professionals, in addition to the adversities of taking care of the baby alone in the first days at home.

Criterion validity evidence was found; however, the specific factors need to be further studied in additional experiments. Given this context, the dimensions 4, 5 and 6 pointed to low criterion validity indexes. Such a phenomenon may have occurred due to, when assigning a score to the Social Support dimension or placing such a construct as perceived at the time of the baby's hospitalization, it could be assumed that the mothers were thinking about Social Support in general, which, in turn, may or may not contemplate the specific characteristics of some of the dimensions mentioned above. However, it should be noted that the analysis carried out in the present study allowed researchers to verify that the instrument has evidence of satisfactory criterion validity when based on the total Social Support score, as well as a general instrument. Thus, it is considered that its use is promising to understand the Social Support perception of mothers of hospitalized premature babies.

\section{Conclusion}

Social support is a construct that has been presented in the literature as being associated with health benefits for individuals. In this case, a better perception of social support, made available by their support networks, tends to be associated with a better health. Considering that the mothers of premature babies who stay in the hospital with their children, hospitalized in the NICU, tend to have their contact with friends and family reduced, it is relevant that their social support be evaluated during this period.

The instrument developed in this study had satisfactory psychometric properties, being suitable for use by different healthcare professionals, being easy and quick to apply. Thus, it is expected that the publication of 
this research will contribute to the access to this scale by the greatest number of professionals, encouraging the assessment of the perceived social support by mothers staying with their premature babies in the NICU.

The construction of a psychological test is a long and laborious process, especially considering the diversity of a country with continental dimensions, such as Brazil. Thus, it is necessary to verify the geopolitical and sociodemographic characteristics of the population to which the instrument refers, as part of a complementary analysis, which are essential to psychometric studies. Such psychometric adjustments must be designed for continuous evaluations (Sousa, Rocha, \& Alchieri, 2011). Thus, it is intended to continue with the improvement of the scale developed in this study through the investigation of more evidences of validity, as well as the search for a greater understanding regarding the association between the perceived social support and the investigated sociodemographic variables.

\section{Contributors}

M. M. C. D. FONSECA contributed to the development of the thesis from which this study is drawn and in the construction of the results, discussion, and conclusion of the article. E. M. C. MAIA guided the thesis and assisted in writing the introduction of the article. J. C. ALCHIERI co-guided the thesis and assisted in writing the introduction and method sections of the article. B. A. A. SILVA contributed to the construction of the introduction and discussion sections. H. K. C. SOUSA contributed to the construction of the results and discussions of the article.

\section{References}

Almeida, N. M. C., \& Arrais, A. R. (2016). O pré-natal psicológico como programa de prevenção à depressão pós-parto. Psicologia Ciência e Profissão, 36(4), 847-863. http://dx.doi.org/10.1590/1982-3703001382014

Almeida, C., R., Morais, A. C., Lima, K., D. F., \& Silva, A. C. O. C. (2018). Cotidiano de mães acompanhantes na unidade de terapia intensiva neonatal. Revista de enfermagem UFPE Online, 12(7), 1949-1956. http://dx.doi.org/10.5205/19818963-v12i7a22640p1949-1956-2018

Baseggio, D. B., Dias, M. P. S., Brusque, S. R., Donelli, T. M. S., \& Mendes, P. (2017). Vivências de mães e bebês prematuros durante a internação neonatal. Temas em Psicologia, 25(1), 153-167. http://dx.doi.org/10.9788/TP2017.1-10

Cardoso, A. C. A., \& Vivian, A. G. (2017). Maternidade e suas vicissitudes: a importância do apoio social no desenvolvimento da díade mãe-bebê. Diaphora, 17(1), 43-51. Recuperado de http://www.sprgs.org.br/diaphora/ojs/index.php/diaphora/ article/view/134/139

Carvalho, L. D. S., \& Pereira, C. D. M. C. (2017). As reações psicológicas dos pais frente à hospitalização do bebê prematuro na UTI neonatal. Revista da SBPH, 20(2), 101-122. Recuperado de http://pepsic.bvsalud.org/pdf/rsbph/ v20n2/v20n2a07.pdf

Coelho, A., S. Custódio, D. C. G. G., Silva, J. D. S. C., Rosso, G., Silva, R., \& Carniel, F. (2018). Equipe de enfermagem e a assistência humanizada na UTI neonatal. Revista Ciência e Saberes-Facema, 4(1), 874-878. Recuperado de http:// www.facema.edu.br/ojs/index.php/ReOnFacema/article/view/381

Contim, D., Ranuzi, C., Gonçalves, J. R. L., Bracarense, C. F., Amaral, J. B., \& Costa, N. S. (2017). Dificuldades vivenciadas por mães de recém-nascidos prematuros durante permanência prolongada em ambiente hospitalar. Revista de Enfermagem e Atenção à Saúde, 6(1), 31-38. http://dx.doi.org/10.18554/reas.v6i1.1684

Dittz, E. S., Mota, J. A. C., \& Sena, R. R. (2008). O cotidiano no alojamento materno, das mães de crianças internadas em uma unidade de terapia intensiva neonatal. Revista Brasileira de Saúde Materno Infantil, 8(1), 75-81. http://dx.doi. org/10.1590/S1519-38292008000100009

Figueiredo, D., \& Silva, J. (2010) Visão além do alcance: uma introdução à análise fatorial. Opinião Pública, 16(1), 160-185. http://dx.doi.org/10.1590/S0104-62762010000100007

Fonseca, M. M. C. D. (2016). Apoio social em mães de bebês prematuros hospitalizados: elaboração e evidência de validade de um instrumento (Dissertação de doutorado não-publicada). Universidade Federal do Rio Grande do Norte. Recuperado de https://repositorio.ufrn.br/jspui/handle/123456789/23302 
Griep, R. H., Chor, D., Faerstein, E., Werneck, G., \& Lopes, C. (2005). Validade de constructo de escala de apoio social do Medical Outcomes Study adaptada para o português no Estudo Pró-Saúde. Caderno de Saúde Pública, 21(3), 703-714. http://dx.doi.org/10.1590/S0102-311X2005000300004

Higuti, P. C. L., \& Capocci, P. O. (2003). Depressão pós-parto. Revista de Enfermagem Unisa, 4, 46-50. Recuperado de http://www.unisa.br/graduacao/biologicas/enfer/-revista/arquivos/2003-11.pdf

Hopkins, J., \& Campbell, S. B. (2008). Development and validation of a scale to assess social support in the postpartum period. Archives of Women's Mental Health, 11(1), 57-65. http://dx.doi.org/10.1007/s00737-008-0212-5

Mingoti, S. A. (2005). Análise de dados através de métodos de estatística multivariada. Belo Horizonte: Editora UFMG.

Ministério da Saúde (Brasil). (2017). Atenção humanizada ao recém-nascido: método canguru. Brasília: Autor. Recuperado de http://bvsms.saude.gov.br/bvs/publicacoes/atencao_humanizada_metodo_canguru_manual_3ed.pdf

Molina, R. C. M., Higarashi, I. H., \& Marcon, S. S. (2014). Importância atribuída à rede de suporte social por mães com filhos em unidade intensiva. Escola Anna Nery, 18(1), 60-67. http://dx.doi.org/10.5935/1414-8145.20140009

Monteiro, K. A., Godoi, B. N., Toledo, O. R., David, F. L., Avelino, M. M., \& Moraes, E. V. (2018). Evidências de sintomatologia depressiva no pós-parto imediato. Revista Brasileira de Ciências da Saúde, 22(4), 379-388. http://dx.doi.org/10.4034/ RBCS.2018.22.04.12

Montirosso, R., Provenzi, L., Calciolari, G., \& Borgatti, R. (2011). Measuring maternal stress and perceived support in 25 Italian NICUs. Acta Pediatrica, 101(2), 136-142. http://dx.doi.org/10.1111/j.1651-2227.2011.02440.x

Oliveira, K., Veronez, M., Higarashi, I. H., \& Corrêa, D. A. M. (2013). Vivências de familiares no processo de nascimento e internação de seus filhos em UTI neonatal. Escola Anna Nery, 17(1), 46-53. http://dx.doi.org/10.1590/S1414-8 1452013000100007

Russel, G., Sawyer, A., Rabe, H., Abbott, J., Gyte, G., Duley, L., ... Ayers, S. (2014). Parent's views on care of their very premature babies in neonatal intensive care units: a qualitative study. BMC Pediatrics, 14(230), 1-10. http://dx.doi. org/10.1186/1471-2431-14-230

Santos, L. M., Oliveira, I. L., Passos, S. D. S. S., Santana, R. C. B., Silva, J. D., \& Lisboa, S. D. (2013). Mudanças familiares decorrentes da hospitalização do prematuro em cuidados intensivos: um estudo com puérperas. Revista Baiana de Enfermagem, 27(3), 230-238. http://dx.doi.org/-10.18471/rbe.v27i3.8684

Schaefer, M. P., \& Donelli, T. M. S. (2017). Psicoterapia mãe-bebê: uma intervenção no contexto da prematuridade. Contextos Clínicos, 10(1), 33-47. http://dx.doi.org/10.4013/ctc.2017.101.03

Sherbourne, C. D., \& Stewart, A. L. (1991). The MOS social support survey. Social Science e Medicine, 38, $705-714$. http://doi.org/10.1016/0277-9536(91)90150-B

Simioni, A. D. S., \& Geib, L. T. C. (2008). Percepção materna quanto ao apoio social recebido no cuidado às crianças prematuras no domicílio. Revista Brasileira de Enfermagem, 61(5). http://dx.doi.org/10.1590/S003471672008000500003

Sousa, H. K. C., Rocha, H. R. R. P., \& Alchieri, J. C. (2011). Millon Clinical Multiaxial Inventory-III: tradução e adaptação semântica dos itens para o Brasil. Aletheia, 35-36, 168-178. Recuperado de http://pepsic.bvsalud.org/scielo. php?script=sci_arttext\&pid=S1413-03942011000200013

Word Health Organization. (2018). Nascimentos prematuros. Geneva: Autor. Recuperado de http://www.who.int/es/ news-room/fact-sheets/detail/preterm-birth

Zanfolim, L. C., Cerchiari, E. A. N., \& Ganassin, F. M. H. (2018). Dificuldades vivenciadas pelas mães na hospitalização de seus bebês em unidades neonatais. Psicologia: Ciência e Profissão, 38(1), 22-35. http://dx.doi.org/10.1590/19823703000292017

Zanini, D. S., Peixoto, E. M., \& Nakano, T. D. C. (2018). Escala de apoio social (MOS-SSS): proposta de normatização com referência nos itens. Trends in Psychology, 26(1), 387-399. http://dx.doi.org/10.9788/TP2018.1-15Pt

Received: September 26, 2019

Final version: December 17, 2019

Approved: April 16, 2020 